\title{
Seasonal variations of the biometric indices of Patella rustica Linnaeus, 1758 (Gastropoda Patellidae) from contrasted sites of the western Algerian coast
}

\author{
Lilia Ait Mohamed Amer ${ }^{1,2, *}$, Imene Benali ${ }^{1,3}$, Saliha Dermeche' \& Mohamed Bouderbala' \\ ${ }^{1}$ Laboratory: Network for Environmental Monitoring (LRSE), Department of Biology, University of Oran 1 "Ahmed Ben Bella", \\ BP 1524 El M'naouer, 31000 Oran, Algeria \\ ${ }^{2}$ Department Science of the Sea and Aquaculture, Faculty of Nature and Life Science, University of Mostaganem Ahmed Ibn Badis, \\ (Ex-Institute of Agricultural Technology, ITA) 2700 Mostaganem, Algeria \\ ${ }^{3}$ Department of Applied Molecular Genetics, Faculty of Natural and Life Sciences, University of Science and Technology Mohamed \\ Boudiaf USTO/MB, BP 1505 El Menaouar, 31036 Oran, Algeria \\ *Corresponding author
}

ABSTRACT

The objective of this study is the evaluation of the resistance of the bioindicative species Patella rustica Linnaeus, 1758 (Gastropoda Patellidae) existing in the contrasted sites of the Algerian occidental seaboard through a follow-up of the seasonal variations of biometric indices. It is based on the analysis of biometric parameters of 600 individuals of this Gastropod mollusk from five sites: Madagh (MD), Bouzedjar Harbor (BH), Ain El Turck (AT), Oran Harbor (OH), and Kristel (KR). The seasonal sampling has been carried out and measurements on the height of the shell (H), its length (L), and its total weight (TW) are taken for all the populations of $P$. rustica. The correlation of the different measurements (length-height, length-total weight, height-total weight), with the help of the power curve and following STUDENT " $t$ " test, DUNCAN, and the ACP, reveals the development of its shell first in height, followed in second position by the length, and this for the five sites under study. Weight would thus be the parameter under analysis that evolves the least quickly as compared to the other two biometric parameters involving a generally significant difference between the five sites under study. These results confirm that the growth of this mollusk varies depending on the seasons and relies on many biotic and abiotic factors that also condition the development of the shell and the growth of limpet. This approach represents a good means for environmental evaluation that could be used in biomonitoring programs to indicate the impact of pollution in the short and long term.

KEY WORDS Algerian occidental coastline; biometric indices; Biomonitoring; Patella rustica.

Received 12.06.2018; accepted 25.07.2018; printed 30.09.2018; published online 05.10.2018

\section{INTRODUCTION}

The totality of the planet's ecosystems is affected one way or another by the developments of human societies and the various waste rejections that could lead to high pollution levels in the coastal marine ecosystems (Smolders et al., 2003; Rao et al., 2007; D'Adamo et al., 2008). These waste rejections of urban, agricultural, and industrial origin alter communities and affect the organisms that compose them (Boening, 1999; Viaroli et al., 2005; Warwick, 2005). The port areas, which are considered the most polluted of the coastal regions, threaten the benthic and pelagic communities 
(Guerra-García \& García-Gómez, 2004).Waste waters, which in many countries are not or only rarely treated, transport and dump their pollutants and organic matters into the coastal waters, thus creating eutrophisation and the bio-accumulation of toxic elements in the marine organisms whose transport all along the food chain represents a danger for human health (Boening, 1999; Daby, 2006).

The same observation is valid for Algeria. Thus, during the last decades, the coastal zones have been the site of an accelerated development and a very important demographic pressure. Around $45 \%$ of the populations are concentrated on a narrow band of the coast, in particular in the industrial and port zones like Algiers, Oran, Annaba, Arzew, and Skikda (Grimes et al., 2004). According to the same author, the population density in the coastal cities is of 281 inhabitants per square kilometer, while the national population density is of 12.2 inhabitants per square kilometer. This statement highlights the importance of having safe and healthy drinking water for such concentrated population.

Biomonitoring of water quality of the various ecosystems requires the use of sentinel organisms such as the mollusk (Long \& Nilson, 1997). The limpet is a gastropod mollusk that has so far been, until now, very little explored to eco-toxicological ends. This mollusk is capable of an extraordinary adaptation to the different variations of ecological factors (Vermeij, 1973; Branch, 1981) and corresponds to the criteria of a good pollution bioindicator: sedentary, sessile, ubiquitous, easy to collect, capable of accumulating and tolerating strong concentrations of exogenous substances of anthropogenic origin (Nakhlé et al., 2006). It offers good resistance to the physic-chemical fluctuations of the environment (temperature, salinity, chemical contaminants, etc.) (Wilson, 1904; Smith, 1935; Dodd, 1955; Damen et al., 1994; Klerkx et al., 2001; Lespinet et al., 2002).

The limpets are invertebrate organisms found in masses on the rocky coasts of the intertidal and subtidal zone (Nakhlé et al., 2003). All the existing species of the genus Patella Linnaeus, 1758 (Gastropoda Patellidae) are limited to the North-East Atlantic and the Mediterranean Sea (Ridgway et al., 1998).

Nevertheless, the biomonitoring studies realized on this bioindicator species of the Algerian occidental coast have been performed using a biochemical ap- proach such as biomarkers measurements, which could be very expensive (Benaissa et al., 2017). For this reason, it is necessary to develop less costly, more practical, and faster approaches based on the monitoring of morphometric parameters in this limpet.

In fact, the morphological variations can inform us of an eventual stress caused on the latter, which can be explained by the change in environmental conditions such as the availability of food and the various anthropic rejections (Beldi et al., 2012).

It is in this perspective that we have realized the follow-up of seasonal variations of the biometric indices through ponderal and linear measurements of the bioindicating species $P$. rustica Linnaeus, 1758 with the concern in the evaluation of the quality of coastal waters of the Algerian occidental coastline.

\section{MATERIAL AND METHODS}

\section{Sampling}

The choice of the sites is in relation to the different sources of pollution. Our samplings are realized at the level of five sites of the Algerian western coast (Fig. 1):

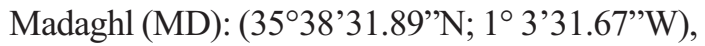
non impacted zone, which is found in a bay closed on its extremities by two small capes restricting the action of the winds. The proximity of Habibas Islands, considered as a protected area (MPA), could make of this coastal site a referential station for comparative studies.

Bouzedjar harbor (BH): $\left(35^{\circ} 34^{\prime} 30.05^{\prime \prime} \mathrm{N}\right.$; $\left.1^{\circ} 10^{\prime} 6.58^{\prime \prime} \mathrm{W}\right)$, zone that benefits from a touristic planning plan that creates an important human frequentation on its site.

Ain El Turck (AT): $\left(35^{\circ} 44^{\prime} 35.13^{\prime \prime} \mathrm{N}\right.$; $\left.0^{\circ} 45^{\prime} 15.55^{\prime} \mathrm{W}\right)$, the site is situated near a desalination station.

Oran harbor $(\mathrm{OH}): \quad\left(35^{\circ} 42^{\prime} 47.87^{\prime \prime} \mathrm{N}\right.$; $0^{\circ} 38^{\prime} 40.57^{\prime \prime} \mathrm{W}$ ), open on the south bank of the western Mediterranean Sea. Situated at less than 200 $\mathrm{kms}$ from the Iberian coast, the Oran harbor constitutes the first harbor of the western Algeria.

Kristel (KR): (3549’32.20”N ; 0²9’22.16”W), is relatively healthy and located between two capes forming the large bay of Oran, Cap Ferrat in the north and Cap Falcon in the south-east. It is situated at 28 $\mathrm{kms}$ from the Kristel site, and harbors a small and picturesque port where artisanal fishing is practiced. 


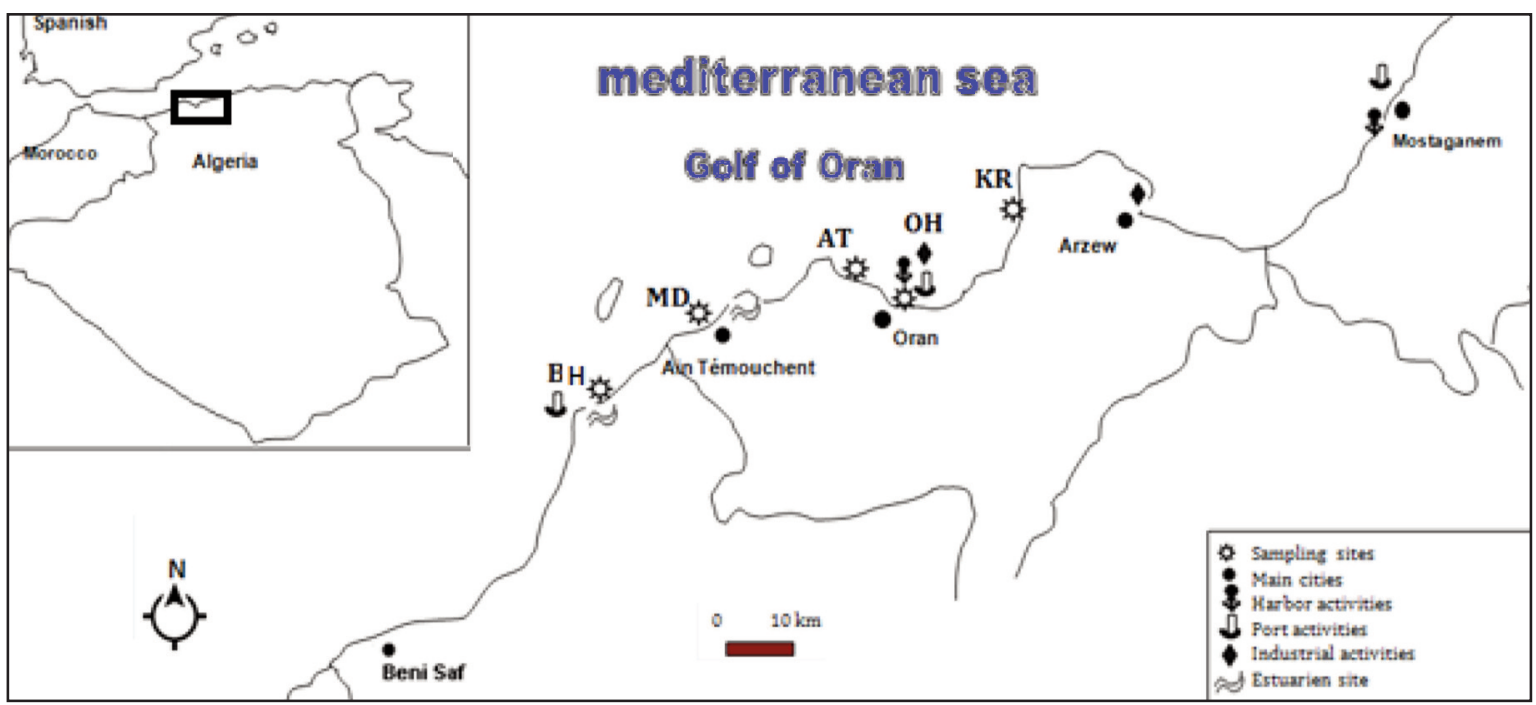

Figure 1. Study area: western Algerian coast.

\section{Experimental sites summary}

1. Kristel (KR), Ain El Turk (AT), and Madagh1 (MD): considered as relatively healthy sites with a slightly marked anthropic activity (sporadic pollution).

2. Bouzedejar harbor $(\mathrm{BH})$ and Oran harbor $(\mathrm{OH})$ : polluted sites found on different geographical positions and substrata.

Collection and preparation of samples of $\mathbf{P}$. rustica

The species $P$. rustica, being different from other limpet species and very easy to see and detect to the naked eye, is sought in all favorable environments and handpicked using leverage. Six hundred specimen of $P$. rustica limpet have been collected during the four seasons of the year 2014 to 2015, 30 specimens per season per site. The limpets have been stored in a cooler at $4^{\circ} \mathrm{C}$ containing seawater of the ambient environment.

In the laboratory, a series of linear measurements using a vernier caliper (to $1 / 100$ th $\mathrm{mm}$ ), are realized, i.e., the length of the shell (L), the height of the shell $(\mathrm{H})$, and the total weight of the specimen (TW) (hard weight and soft weight) with the help of a precision scale (to $1 / 100$ th $\mathrm{g}$ ).

The interpretation of these different measurements are correlated with a power curve of the form $\mathrm{y}=\mathrm{axb}$ (Myers, 1986), which is transformed into a $\operatorname{logarithmic}$ function of form: $\log \mathrm{y}=\log \mathrm{a}+\mathrm{b} \log$ $\mathrm{x}$. This transformation is the simplest method to linearize the relationship, stabilize the variances and normalize the variables (Myers, 1986). It is admitted that the variables measured are without significant errors, since the method of calculation adopted is that of the least squares.

Statistica 7.0 has been used for inter-sites comparison biological parameters of $P$. rustica using the DUNCAN test; $\mathrm{P}<0.05$ ), and ACP for the inter-sites and seasonal comparisons, but also the different biometric parameters of the various groups of $P$. rustica.

\section{RESULTS AND DISCUSSION}

The biometric parameters show minima and a maxima values respectively for the length of the shell comprised between $19 \mathrm{~mm}$ and $36 \mathrm{~mm}$, for the height of the shell ( $5 \mathrm{~mm}$ to $14 \mathrm{~mm}$ ), and for the total weight of the values of the order of $1.21 \mathrm{~g}$ to $7.84 \mathrm{~g}$.

The means and typical gaps are represented in Table 1 as well as the marked significance following the DUNCAN test $(\mathrm{P}<0.05)$ between the parameters considered annually and inter-sites. The Annual and seasonal allometric results for $P$. rustica populations are showed in Tables 2, 3, 4, and 5 . 
The analysis of these tables reveals for all the results related to the relation length-height a strong correlation for three seasons (Winter - Spring Summer), which order varies from $72 \%$ to $93 \%$ $(\mathrm{P}<0.05)$ (Table 3) for the five sites considered, whereas Autumn is attributed the lowest values (67\% to $77 \%$ ). These values witness a good correlation of the two linear parameters $(\mathrm{L}-\mathrm{H})$. We see a good autumnal correlation of $60 \%$ and $70 \%$, going up to a strong correlation of the order of $94 \%$ for the other three seasons.

The two parameters of $\mathrm{L}$ and $\mathrm{H}$ and following test " $T$ " show a minor allometry (for the four seasons and for the five sites), which means that $\mathrm{L}$ grows more slowly than $\mathrm{H}$.

The annual study of the coupled interaction of TW-L reveals a strong correlation between these latter two with a coefficient of 0.74 and 0.81 $(\mathrm{P}<0.05)$ for $\mathrm{BH}$, between 0.54 and 0.91 for $\mathrm{KR}$, 0.68 and 0.96 for AT, 0.77 and 0.90 for MD, 0.69 and 0.90 finally for $\mathrm{OH}$ (Table 4). As for the preceding two parameters, the correlation between TW and L varies between strong in autumn to very strong for the other three seasons. Factor b marks a significant minor allometry and sometimes on for the winter, summer, and autumn seasons $(b<2.5)$, which means a less important development of TW than the L of the shell. In addition, factor $b$ marks an isometric in spring $(b>2.5 \approx 3)$, which explains that the TW evolves at the same speed as the L of the shell apart from AT (Baibbat \& Abid, 2015).

Finally, the co-evolution of TW and $\mathrm{H}$ has in turn revealed a correlation coefficient varying between 0.64 and 0.87 for $\mathrm{BH}(\mathrm{P}<0.05)$, from 0.64 to 0.91 for $\mathrm{KR}, 0.52$ to 0.90 for AT, 0.70 to 0.90 for $\mathrm{MD}$ and finally 0.50 to 0.93 for $\mathrm{OH}$ (Table 5). Test $\mathrm{T}$ reveals significance between the two parameters and a minor allometry for all the stations and during the whole year, which shows that the $\mathrm{H}$ grows faster than TW.

The Morphometric parameters measured in the limpet in the five sites ( $\mathrm{BH}, \mathrm{KR}, \mathrm{AT}, \mathrm{MD}, \mathrm{OH})$ have been integrated in a multi-varied analysis so as to detect the models of variation. The correlation circle formed by F1 and F2 indicates an axis that shows $88.7 \%$ of the total information. The two main components PC1 and PC2 have been identified as representing respectively $33.01 \%$ and $18.62 \%$ of the total variance.
PC1 is negatively correlated with all parameters. PC2 is positively correlated with the three parameters ( $\mathrm{L}, \mathrm{H}, \mathrm{TW})$ of MD, BH and also with the L parameters of $\mathrm{OH}$ and $\mathrm{AT}$. On the contrary, $\mathrm{PC} 2$ is negatively correlated with the three parameters (L, H, TW) of $\mathrm{KR}$ and also (H and TW) of the $\mathrm{OH}$ and AT.

There are of the correlations between the different sampling seasons and F1 and F2 shown $98 \%$ of the total information. They represent respectively $96.26 \%$ and $1.57 \%$ and they also give a good description of most of the studied parameters. PC1 is

\begin{tabular}{|cccccc|}
\hline $\begin{array}{c}\text { Sites } \\
\text { Parameters }\end{array}$ & BH & KR & AT & MD & OH \\
\hline & & & & & \\
lengths & $27.78 \pm 2.83^{\mathrm{a}}$ & $26.16 \pm 2.38^{\mathrm{b}}$ & $24.66 \pm 3.30^{\mathrm{c}}$ & $23.91 \pm 3.46^{\mathrm{c}}$ & $27.09 \pm 4.23^{\mathrm{a}}$ \\
height & $10.03 \pm 1.80^{\mathrm{a}}$ & $8.63 \pm 1.30^{\mathrm{b}}$ & $8.58 \pm 1.71^{\mathrm{b}}$ & $8.61 \pm 1.72^{\mathrm{b}}$ & $8.77 \pm 1.68^{\mathrm{b}}$ \\
& & & & & \\
total weight & $3.57 \pm 1.11^{\mathrm{a}}$ & $3.91 \pm 0.84^{\mathrm{b}}$ & $3.28 \pm 0.83^{\text {cd }}$ & $3.07 \pm 0.95^{\mathrm{d}}$ & $3.54 \pm 1.46^{\mathrm{ac}}$ \\
\hline
\end{tabular}

Table 1. Averages and standard deviations of the lengths, height, and total weight of limpets collected seasonally at the five study sites.

\begin{tabular}{|c|c|c|c|c|c|}
\hline STATIONS & EQUATION & $\mathbf{N}$ & $\mathbf{R}$ & $\begin{array}{l}\text { ALLOMETRY } \\
\text { TEST }\end{array}$ & ALLOMETRY \\
\hline BH & $\begin{array}{l}\mathrm{L}=0.0608 \mathrm{H}^{1.5336} \\
\mathrm{P}=0.1812 \mathrm{~L}^{1.2815} \\
\mathrm{P}=0.0009 \mathrm{H}^{2.4757}\end{array}$ & $\begin{array}{l}120 \\
120 \\
120\end{array}$ & $\begin{array}{l}0.759 \\
0.5809 \\
0.6995\end{array}$ & $\begin{array}{l}* * \\
* * \\
* *\end{array}$ & $\begin{array}{l}\text { Minorante } \\
\text { Minorante } \\
\text { Minorante }\end{array}$ \\
\hline KR & $\begin{array}{l}\mathrm{L}=8.55 \mathrm{H}^{0.5195} \\
\mathrm{~W}=0.0083 \mathrm{~L}^{1.8829} \\
\mathrm{~W}=0.2654 \mathrm{H}^{1.2444}\end{array}$ & $\begin{array}{l}120 \\
120 \\
120\end{array}$ & $\begin{array}{l}0.7045 \\
0.6638 \\
0.7569\end{array}$ & $\begin{array}{l}* * \\
* * \\
* *\end{array}$ & $\begin{array}{l}\text { Minorante } \\
\text { Minorante } \\
\text { Minorante }\end{array}$ \\
\hline AT & $\begin{array}{l}\mathrm{L}=7.3001 \mathrm{H} \\
\mathrm{W}=0.0153 \mathrm{~L}^{1.6705} \\
\mathrm{~W}=0.326 \mathrm{H}^{1.0686}\end{array}$ & $\begin{array}{l}120 \\
120 \\
120\end{array}$ & $\begin{array}{l}0.6766 \\
0.768 \\
0.6613\end{array}$ & $\begin{array}{l}* * \\
* * \\
* *\end{array}$ & $\begin{array}{l}\text { Minorante } \\
\text { Minorante } \\
\text { Minorante }\end{array}$ \\
\hline MD & $\begin{array}{l}\mathrm{L}=7.1308 \mathrm{H}^{0.5625} \\
\mathrm{~W}=0.0084 \mathrm{~L}^{1.8522} \\
\mathrm{~W}=0.2921 \mathrm{H}^{1.0836}\end{array}$ & $\begin{array}{l}120 \\
120 \\
120\end{array}$ & $\begin{array}{l}0.6468 \\
0.785 \\
0.5492\end{array}$ & $\begin{array}{l}* * \\
* * \\
* *\end{array}$ & $\begin{array}{l}\text { Minorante } \\
\text { Minorante } \\
\text { Minorante }\end{array}$ \\
\hline $\mathrm{OH}$ & $\begin{array}{l}\mathrm{L}=8.3932 \mathrm{H}^{0.5388} \\
\mathrm{~W}=0.0016 \mathrm{~L}^{2.3094} \\
\mathrm{~W}=0.0985 \mathrm{H}^{1.6263}\end{array}$ & $\begin{array}{l}120 \\
120 \\
120\end{array}$ & $\begin{array}{l}0.4472 \\
0.7691 \\
0.5876\end{array}$ & $\begin{array}{l}* * \\
* * \\
* *\end{array}$ & $\begin{array}{l}\text { Minorante } \\
\text { Minorante } \\
\text { Minorante }\end{array}$ \\
\hline
\end{tabular}

Table 2. Overall allometric equations between length, height and total weight of P. rustica in the five stations (BH), (KR), (AT), (MD), and $(\mathrm{OH})$ during the four seasons of the year. $\mathrm{N}$ : Number of individuals; R: Coefficient of correlation of regression equations; **: Significant Student Test $(\mathrm{P}<0.05)$. 


\begin{tabular}{|c|c|c|c|c|c|c|}
\hline STATIONS & SEASONS & EQUATION & $\mathbf{N}$ & $\mathbf{R}$ & $\begin{array}{c}\text { ALLOMETRY } \\
\text { TEST }\end{array}$ & ALLOMETRY \\
\hline BH & $\begin{array}{l}\text { Winter } \\
\text { Spring } \\
\text { Summer } \\
\text { Autumn }\end{array}$ & $\begin{array}{l}\mathrm{L}=8.2528 \mathrm{H}^{0.5239} \\
\mathrm{~L}=8.9992 \mathrm{H}^{0.494} \\
\mathrm{~L}=7.4993 \mathrm{H}^{0.5585} \\
\mathrm{~L}=8.784 \mathrm{H}^{0.5123}\end{array}$ & $\begin{array}{l}30 \\
30 \\
30 \\
30 \\
\end{array}$ & $\begin{array}{l}0.8012 \\
0.8325 \\
0.8017 \\
0.6838 \\
\end{array}$ & $\begin{array}{l}* * \\
* * \\
* * \\
* * \\
\end{array}$ & $\begin{array}{l}\text { Minorante } \\
\text { Minorante } \\
\text { Minorante } \\
\text { Minorante }\end{array}$ \\
\hline $\mathbf{K R}$ & $\begin{array}{l}\text { Winter } \\
\text { Spring } \\
\text { Summer } \\
\text { Autumn }\end{array}$ & $\begin{array}{l}\mathrm{L}=7.8476 \mathrm{H}^{0.5693} \\
\mathrm{~L}=12.649 \mathrm{H}^{0.3573} \\
\mathrm{~L}=7.12 \mathrm{H}^{0.5776} \\
\mathrm{~L}=9.2642 \mathrm{H}^{0.4833}\end{array}$ & $\begin{array}{l}30 \\
30 \\
30 \\
30\end{array}$ & $\begin{array}{l}0.9145 \\
0.8619 \\
0.8828 \\
0.6926\end{array}$ & $\begin{array}{l}* * \\
* * \\
* * \\
* *\end{array}$ & $\begin{array}{l}\text { Minorante } \\
\text { Minorante } \\
\text { Minorante } \\
\text { Minorante }\end{array}$ \\
\hline $\mathbf{A T}$ & $\begin{array}{l}\text { Winter } \\
\text { Spring } \\
\text { Summer } \\
\text { Autumn }\end{array}$ & $\begin{array}{l}\mathrm{L}=7.3911 \mathrm{H}^{0.6067} \\
\mathrm{~L}=8.4299 \mathrm{H}^{0.5092} \\
\mathrm{~L}=6.3764 \mathrm{H}^{0.6009} \\
\mathrm{~L}=7.7838 \mathrm{H}^{0.5146}\end{array}$ & $\begin{array}{l}30 \\
30 \\
30 \\
30 \\
\end{array}$ & $\begin{array}{l}0.9166 \\
0.9253 \\
0.9012 \\
0.7649 \\
\end{array}$ & $\begin{array}{l}* * \\
* * \\
* * \\
* *\end{array}$ & $\begin{array}{l}\text { Minorante } \\
\text { Minorante } \\
\text { Minorante } \\
\text { Minorante }\end{array}$ \\
\hline MD & $\begin{array}{l}\text { Winter } \\
\text { Spring } \\
\text { Summer } \\
\text { Autumn }\end{array}$ & $\begin{array}{l}\mathrm{L}=8.1148 \mathrm{H}^{0.5579} \\
\mathrm{~L}=5.9738 \mathrm{H}^{0.6414} \\
\mathrm{~L}=7.113 \mathrm{H}^{0.5378} \\
\mathrm{~L}=7.6723 \mathrm{H}^{0.4996}\end{array}$ & $\begin{array}{l}30 \\
30 \\
30 \\
30\end{array}$ & $\begin{array}{l}0.9085 \\
0.9225 \\
0.936 \\
0.7755\end{array}$ & $\begin{array}{l}* * \\
* * \\
* * \\
* *\end{array}$ & $\begin{array}{l}\text { Minorante } \\
\text { Minorante } \\
\text { Minorante } \\
\text { Minorante }\end{array}$ \\
\hline $\mathbf{O H}$ & $\begin{array}{l}\text { Winter } \\
\text { Spring } \\
\text { Summer } \\
\text { Autumn }\end{array}$ & $\begin{array}{l}\mathrm{L}=5.767 \mathrm{H}^{0.706} \\
\mathrm{~L}=12.446 \mathrm{H}^{0.423} \\
\mathrm{~L}=7.017 \mathrm{H}^{0.6345} \\
\mathrm{~L}=8.7414 \mathrm{H}^{0.4569}\end{array}$ & $\begin{array}{l}30 \\
30 \\
30 \\
30\end{array}$ & $\begin{array}{l}0.7244 \\
0.9375 \\
0.9087 \\
0.6767\end{array}$ & $\begin{array}{l}* * \\
* * \\
* * \\
* *\end{array}$ & $\begin{array}{l}\text { Minorante } \\
\text { Minorante } \\
\text { Minorante } \\
\text { Minorante }\end{array}$ \\
\hline
\end{tabular}

Table 3. Annual allometric equations between shell length of $P$. rustica and its height in the five stations (BH), (KR), (AT), (MD), and $(\mathrm{OH})$ during the study year. N: Number of individuals; R: Coefficient of correlation of regression equations; **: Significant Student Test $(\mathrm{P}<0.05)$.

\begin{tabular}{|c|c|c|c|c|c|c|}
\hline STATIONS & SEASONS & EQUATION & $\mathbf{N}$ & $\mathbf{R}$ & $\begin{array}{c}\text { ALLOMETRY } \\
\text { TEST }\end{array}$ & ALLOMETRY \\
\hline BH & $\begin{array}{l}\text { Winter } \\
\text { Spring } \\
\text { Summer } \\
\text { Autumn }\end{array}$ & $\begin{array}{l}\mathrm{W}=0.0019 \mathrm{~L}^{2.2695} \\
\mathrm{~W}=0.0004 \mathrm{~L}^{2.769} \\
\mathrm{~W}=0.0012 \mathrm{~L}^{2.3496} \\
\mathrm{~W}=0.0021 \mathrm{~L}^{2.2566}\end{array}$ & $\begin{array}{l}30 \\
30 \\
30 \\
30\end{array}$ & $\begin{array}{l}0.7856 \\
0.7968 \\
0.8131 \\
0.7458\end{array}$ & $\begin{array}{l}* * \\
* * \\
* * \\
* *\end{array}$ & $\begin{array}{l}\text { Minorante } \\
\text { Isometric } \\
\text { Minorante } \\
\text { Minorante }\end{array}$ \\
\hline $\mathbf{K R}$ & $\begin{array}{l}\text { Winter } \\
\text { Spring } \\
\text { Summer } \\
\text { Autumn }\end{array}$ & $\begin{array}{l}\mathrm{W}=0.0094 \mathrm{~L}^{1.8035} \\
\mathrm{~W}=0.0002 \mathrm{~L}^{2.9906} \\
\mathrm{~W}=0.011 \mathrm{~L}^{1.8068} \\
\mathrm{~W}=0.0124 \mathrm{~L}^{1.7878}\end{array}$ & $\begin{array}{l}30 \\
30 \\
30 \\
30 \\
\end{array}$ & $\begin{array}{l}0.8109 \\
0.9122 \\
0.8916 \\
0.543\end{array}$ & $\begin{array}{l}* * \\
* * \\
* * \\
* *\end{array}$ & $\begin{array}{l}\text { Minorante } \\
\text { Isometric } \\
\text { Minorante } \\
\text { Minorante }\end{array}$ \\
\hline AT & $\begin{array}{l}\text { Winter } \\
\text { Spring } \\
\text { Summer } \\
\text { Autumn }\end{array}$ & $\begin{array}{l}\mathrm{W}=0.0104 \mathrm{~L}^{1.7746} \\
\mathrm{~W}=0.0063 \mathrm{~L}^{1.934} \\
\mathrm{~W}=0.0023 \mathrm{~L}^{2.3162} \\
\mathrm{~W}=0.0062 \mathrm{~L}^{1.9393}\end{array}$ & $\begin{array}{l}30 \\
30 \\
30 \\
30 \\
\end{array}$ & $\begin{array}{l}0.8775 \\
0.944 \\
0.9603 \\
0.6781 \\
\end{array}$ & $\begin{array}{l}* * \\
* * \\
* * \\
* *\end{array}$ & $\begin{array}{l}\text { Minorante } \\
\text { Minorante } \\
\text { Minorante } \\
\text { Minorante }\end{array}$ \\
\hline MD & $\begin{array}{l}\text { Winter } \\
\text { Spring } \\
\text { Summer } \\
\text { Autumn }\end{array}$ & $\begin{array}{l}\mathrm{W}=0.0745 \mathrm{~L}^{1.1778} \\
\mathrm{~W}=0.0003 \mathrm{~L}^{2.9155} \\
\mathrm{~W}=0.0018 \mathrm{~L}^{2.3202} \\
\mathrm{~W}=0.0189 \mathrm{~L}^{1.5869}\end{array}$ & $\begin{array}{l}30 \\
30 \\
30 \\
30 \\
\end{array}$ & $\begin{array}{l}0.8573 \\
0.9039 \\
0.8712 \\
0.7744 \\
\end{array}$ & $\begin{array}{l}* * \\
* * \\
* * \\
* *\end{array}$ & $\begin{array}{l}\text { Minorante } \\
\text { Isometric } \\
\text { Minorante } \\
\text { Minorante }\end{array}$ \\
\hline $\mathbf{O H}$ & $\begin{array}{l}\text { Winter } \\
\text { Spring } \\
\text { Summer } \\
\text { Autumn }\end{array}$ & $\begin{array}{l}\mathrm{W}=0.0015 \mathrm{~L}^{2.3269} \\
\mathrm{~W}=0.0002 \mathrm{~L}^{2.9304} \\
\mathrm{~W}=0.0003 \mathrm{~L}^{2.7545} \\
\mathrm{~W}=0.0038 \mathrm{~L}^{2.1056}\end{array}$ & $\begin{array}{l}30 \\
30 \\
30 \\
30\end{array}$ & $\begin{array}{l}0.8515 \\
0.8914 \\
0.9037 \\
0.6954\end{array}$ & $\begin{array}{l}* * \\
* * \\
* * \\
* *\end{array}$ & $\begin{array}{l}\text { Minorante } \\
\text { Isometric } \\
\text { Isometric } \\
\text { Minorante }\end{array}$ \\
\hline
\end{tabular}

Table 4. Annual allometric equations between shell length of P. rustica and total weight in the five stations (BH), (KR), (AT), (MD), and $(\mathrm{OH})$ during the study year. N: Number of individuals; R: Coefficient of correlation of regression equations; **: Significant Student Test $(\mathrm{P}<0.05)$. 


\begin{tabular}{|c|c|c|c|c|c|c|}
\hline STATIONS & SEASONS & EQUATION & $\mathbf{N}$ & $\mathbf{R}$ & $\begin{array}{c}\text { ALLOMETRY } \\
\text { TEST }\end{array}$ & ALLOMETRY \\
\hline BH & $\begin{array}{l}\text { Winter } \\
\text { Spring } \\
\text { Summer } \\
\text { Autumn }\end{array}$ & $\begin{array}{l}W=0.1469 H^{1.3794} \\
W=0.0974 H^{1.5712} \\
W=0.0927 H^{1.4659} \\
W=0.2055 H^{1.3026}\end{array}$ & $\begin{array}{l}30 \\
30 \\
30 \\
30\end{array}$ & $\begin{array}{l}0.8472 \\
0.8751 \\
0.8136 \\
0.6472\end{array}$ & $\begin{array}{l}* * \\
* * \\
* * \\
* *\end{array}$ & $\begin{array}{l}\text { Minorante } \\
\text { Minorante } \\
\text { Minorante } \\
\text { Minorante }\end{array}$ \\
\hline $\mathbf{K R}$ & $\begin{array}{l}\text { Winter } \\
\text { Spring } \\
\text { Summer } \\
\text { Autumn }\end{array}$ & $\begin{array}{l}\mathrm{W}=0.3062 \mathrm{H}^{1.1385} \\
\mathrm{~W}=0.3449 \mathrm{H}^{1.1477} \\
\mathrm{~W}=0.3227 \mathrm{H}^{1.1224} \\
\mathrm{~W}=0.3749 \mathrm{H}^{1.1277}\end{array}$ & $\begin{array}{l}30 \\
30 \\
30 \\
30\end{array}$ & $\begin{array}{l}0.9117 \\
0.9072 \\
0.9105 \\
0.6406\end{array}$ & $\begin{array}{l}* * \\
* * \\
* * \\
* *\end{array}$ & $\begin{array}{l}\text { Minorante } \\
\text { Minorante } \\
\text { Minorante } \\
\text { Minorante }\end{array}$ \\
\hline AT & $\begin{array}{l}\text { Winter } \\
\text { Spring } \\
\text { Summer } \\
\text { Autumn }\end{array}$ & $\begin{array}{l}\mathrm{W}=0.3397 \mathrm{H}^{1.1054} \\
\mathrm{~W}=0.3819 \mathrm{H}^{0.9946} \\
\mathrm{~W}=0.1591 \mathrm{H}^{1.4204} \\
\mathrm{~W}=0.3281 \mathrm{H}^{1.0038}\end{array}$ & $\begin{array}{l}30 \\
30 \\
30 \\
30\end{array}$ & $\begin{array}{l}0.8479 \\
0.8909 \\
0.9015 \\
0.5249\end{array}$ & $\begin{array}{l}* * \\
* * \\
* * \\
* *\end{array}$ & $\begin{array}{l}\text { Minorante } \\
\text { Minorante } \\
\text { Minorante } \\
\text { Minorante }\end{array}$ \\
\hline MD & $\begin{array}{l}\text { Winter } \\
\text { Spring } \\
\text { Summer } \\
\text { Autumn }\end{array}$ & $\begin{array}{l}\mathrm{W}=0.799 \mathrm{H}^{0.7008} \\
\mathrm{~W}=0.0498 \mathrm{H}^{1.9405} \\
\mathrm{~W}=0.1484 \mathrm{H}^{1.3145} \\
\mathrm{~W}=0.4199 \mathrm{H}^{0.8563}\end{array}$ & $\begin{array}{l}30 \\
30 \\
30 \\
30\end{array}$ & $\begin{array}{l}0.886 \\
0.8979 \\
0.9049 \\
0.7007\end{array}$ & $\begin{array}{l}* * \\
* * \\
* * \\
* *\end{array}$ & $\begin{array}{l}\text { Minorante } \\
\text { Minorante } \\
\text { Minorante } \\
\text { Minorante }\end{array}$ \\
\hline $\mathbf{O H}$ & $\begin{array}{l}\text { Winter } \\
\text { Spring } \\
\text { Summer } \\
\text { Autumn }\end{array}$ & $\begin{array}{l}\mathrm{W}=0.0448 \mathrm{H}^{1.9585} \\
\mathrm{~W}=0.2972 \mathrm{H}^{1.2928} \\
\mathrm{~W}=0.052 \mathrm{H}^{1.8632} \\
\mathrm{~W}=0.338 \mathrm{H}^{0.9993}\end{array}$ & $\begin{array}{l}30 \\
30 \\
30 \\
30\end{array}$ & $\begin{array}{l}0.8766 \\
0.9093 \\
0.9332 \\
0.5079\end{array}$ & $\begin{array}{l}* * \\
* * \\
* * \\
* *\end{array}$ & $\begin{array}{l}\text { Minorante } \\
\text { Minorante } \\
\text { Minorante } \\
\text { Minorante }\end{array}$ \\
\hline
\end{tabular}

Table 5. Annual allometric equations between shell height of $P$. rustica and total weight in the five stations (BH), (KR), (AT), (MD), and (OH) during the study year. N: Number of individuals; R: Coefficient of correlation of regression equations; **: Significant Student Test $(\mathrm{P}<0.05)$.

negatively correlated with the two cold seasons, winter and autumn. PC2 is positively correlated with the hot seasons, spring and summer.

\section{DISCUSSION}

The study of the biological parameters taken into account in this study highlights an excellent correlation of biometric relations for the five sites of study (Fig. 1), and also for winter, spring, and summer, whereas in autumn this correlation coefficient indicates the lowest values.

This variability could be linked to different factors, whether biotic and/or abiotic (Grimes et al., 2004).

The good development of limpets and the good correlation of the three parameters (length, height, total weight) at the polluted sites $(\mathrm{OH}, \mathrm{BH})$ could be due to the fact that the stations are situated near the urban waste rejection seen as very rich in nutrient salts, which encourages the development of phytobenthos on the medio-littoral and supra-littoral shelf with a strong concentration in spring when phytoplancthonic bloom is at its highest level. This explains the isometric development between length and weight. Generally, temperate limpets grow more rapidly in summer due to the increased abundance of food (Brêthes et al., 1994; Vat, 2000). In the present study, the result shows that there would be a good correlation in the summer and spring period of the whole of the P. rustica populations. For this reason, the marked $\mathrm{R}^{2}$ in summer for all the stations under study is very good. According to Davies (1969), P. rustica occupies the superior intertidal zone whereas $P$. caerulea Linnaeus, 1758 and P. ulyssiponensis Gmelin, 1791 colonize the inferior part of this zone. Grimes et al. (2004) specify that $P$. rustica settles mainly in the inferior mediolittoral where it is found in abundance and where it takes its food resources. This food contributes widely to its physiology development (growth, reproduction) and exerts a direct effect on the speed and duration of gametogenesis phenomena (Lubet, 1980). This explains the slightly important weight obtained in autumn (a period weak in nutrients, but also a period marked by reproduction for $P$. rustica from July to December) (Othaitz, 1994), including 
a correlation of the order of $60 \%$, instead of $80 \%$ to $96 \%$ for the other seasons.

These results are corroborated by Frehi et al. (2007) and Beldi et al. (2012), who approve that the polluted sites are very rich in phytoplankton, which allows $P$. rustica to be a grazing species. The algae cover and the floristic composition play a major role in the abundance of herbivorous (Hereu, 2004).

The $P$. rustica shells present an allometry in their growth in length and in height, because they grow more in height than in length. Our species is considered to be using a strategy of energy conservation due to its unstable environment and its limited food resources. To this effect, it encourages the development of its shell in height in order to be able to store water and thus hydrate itself during prolonged emersion periods (Sokolova \& Pörtner, 2003; Prusina et al., 2014).

Moreover, the growth of the shell and of the total weight of our samples is observed at the level of all the chosen sites, whether they are impacted or not. The biometric relations done on P. rustica specimens taken from MD, KR, and AT show a correlation which is as important as those taken from the two harbors $(\mathrm{OH}$ and $\mathrm{BH})$. This indicates that the limpets of the coastal sector and the two harbors evolve in the same manner and that pollution does not impact on the specimens (same biological equilibrium).

\section{CONCLUSIONS}

This study, based on the biometry of $P$. rustica, was realized in order to evaluate the evolution of the latter from the point of view of total weight, and anteroposterior length of the shell, as well as its height at the level of the different sites having a variable pollution rate. We have shown evidence that this species has the capacity to develop in different environments and that it has shown to be a resilient and resistant species. Following these results, $P$. rustica evolves in its environment given the growth of these biological parameters taken into consideration, and this despite the environment.

Finally, it would be interesting to enlarge the spectrum to several other sampling points of this gastropod mollusk $P$. rustica for a wider and complementary study of these biometric parameters.

\section{REFERENCES}

Baibbat S.A. \& Abid N., 2015. Étude de quelques aspects biologiques des thonidés mineurs débarqués au port de Laayoune et Dakhla. Collective Volume of Scientific Papers ICCAT, 71: 2709-2716.

Beldi H., Boumaza F.Z., Draredja B. \& Soltani N., 2012. Biodiversité des patellidae (Gastropoda, Prosobranchia) du Golfe d'Annaba (Algérie nord-est). Bulletin de la Societe Zoologique de France, 137: 121-132. http://www.snv.jussieu.fr/zoologie

Benaissa M., Rouane-Hacene O., Boutiba Z., GuibboliniSabatier E.M. \& Risso-De Faverney C., 2017. Ecotoxicological impact assessment of the brine discharges from a desalination plant in the marine waters of the Algerian west coast, using a multi biomarker approach in a limpet, Patella rustica. Environmental Science and Pollution Research, 24: 24521-24532. DOI: 10.1007/s11356-017-0081-4.

Boening D.W., 1999. An evaluation of bivalves as biomonitors of heavy metals pollution in marine waters. Environmental monitoring and assessment, 55: 459470.

Branch G.M., 1981. The biology of limpets: physical factors, energy flow and ecological interactions. Oceanography and Marine Biology, An Annual Review, 19: 235-380.

Brêthes J.C., Ferreyra G. \& De La Vega, S., 1994. Distribution, growth and reproduction of the limpet $\mathrm{Na}$ cella (Patinigera) concinna (Strebel 1908) in relation to potential food availability, in Esperanza Bay (Antarctic Peninsula). Polar Biology, 14, 161-170.

Daby D., 2006. Coastal pollution and potential biomonitors of metals in Mauritius. Water, Air and soil pollution, 174: 63-91.

D’Adamo R., Di Stasio M. \& Fabbrochini A., 2008. Migratory crustaceans as biomonitors of metal pollution in their nursery areas. The Lesina lagoon (SE Italy) as a case study. Evironmental monitoring and assessment, 143: 15-24. DOI: org/10.1007/s10661 -0079944-3

Damen W.G.M., Van Grunsven L.A. \& Van Loon A.E., 1994. Transcriptional regulation of tubulin gene expression in differentiating trochoblast during early development of Patella vulgata. Development, 120: 2835-2845.

Davies P.S., 1969. Effect of environment on metabolic activity and morphology of Mediterranean and British species of Patella. Pubblicazioni della Stazione Zoologica di Napoli, 37: 641-656.

Dodd J.M., 1955. Artificial fertilisation, larval development and metamorphosis in Patella vulgata L. and Patella caerulea L. Pubblicazioni della Stazione Zoologica di Napoli, 29: 172-185. 
Frehi H., Couté A., Mascarell G., Pirette-Gallet C., Ayada M. \& Kara M.H., 2007. Dinoflagellés toxiques et/ou responsables de blooms dans la baie d'Annaba (Algérie). Comptes rendus Biologies, 330: 615-628.

Grimes S., Boutiba Z., Bakalem A., Bouberbala M., Boudjellal B., Boumaza S., Boutiba M., Guedioura A., Hafferssas A., Hemida F., Kaïdi N., Khelifi H., Kerzabi F., Merzoug A., Nouara A., Sellali B., Sellali-Merabtine H., Semroud R., Seridi H., Taleb M.Z. \& Touahria T., 2004. Biodiversité marine et côtière algérienne. ISBN 9961-9547-O-X. Ouvrage domicilié au laboratoire "Réseau de surveillance environnementale”. Université Es Sénia, Oran, Algérie, 361 pp.

Guerra-García J.M. \& García-Gómez J.C., 2004. Polychaete assemblages and sediment pollution in a harbour with two opposing entrances. Helgoland marine research, 58: 183-191.

Hereu B., 2004. The role of trophic interactions between fishes, sea urchins and algae in the northwest Mediterranean rocky infralittoral, Thèse Doctorat, Universidad Barcelona, 287 pp.

Klerkx A.H.E.M., De Boer E. \& Van Loon A.E., 2001. Spation temporal expression of a gene encoding a putative RNA- binging protein during the early larval development of the mollusc Patella vulgata. Development Genes and Evolution, 211: 423-427.

Lespinet O., Nederbragt A.J., Cassan M., Dictus W.J.A.G., Van Loon A.E. \& Adoutte A., 2002. Characterisation of two snail genes in the gasteropod mollusk Patella vulgata. Implication for understanding the ancestral function of the snail-related genes in Bilateria. Develoment Genes and Evolution, 212: 186-195.

Long E.R. \& Nilson C.J., 1997. On the identification of toxic hot spots using measures of the sediment quality triad. Environmental Toxicology and Chemistry, 34: 373-374.

Lubet P., Brichon G., Besnard J.Y. \& Zwingelstein G., 1986. Sexual differences in the composition and metabolism of lipids in the mantle of the mussel Mytilus galloprovincialis Lmk (Mollusca: Bivalvia). Comparative Biochemistry \& Physiology, 84B: 279-285.

Nakhle K.F., 2003. Le mercure, le cadmium et le plomb dans les eaux littorals libanaises: apport et suivi au moyens de bioindicateurs quantitatives (éponges, bivalves et gastéropodes), Thèse de Doctorat Univ. Denis Diderot, Paris, France, 246 pp.

Nakhlé K., Cossa D., Khalaf G. \& Beliaeff B., 2006. Brachidontes variabilis and Patella $\mathrm{sp}$. as quantita- tive biological indicators for cadmium, lead and mercury in the Lebanese coastal waters. Environmental Pollution, 142: 73-82.

Prusina I., Ezgeta-Balić D., Jubimir L.S., Dobroslavić T. \& Glamuzina B., 2014. On the reproduction of the Mediterranean keystone limpet Patella rustica: histological overview. Journal of the Marine Biological Association of the UK, 94: 1651-1660.

Rao J.V., Kavitha P., Srikanth K., Usman P.K. \& Rao T.G., 2007. Environmental contamination using accumulation of metals in marine sponges, Sigmadocia fibulata inhabiting the coastal waters of Gulf of Mannar, India. Toxicological and environmental chemestry, 89: 487-498.

Ridgway S.A., Reid D.G., Taylor J.D., Branch G.M. \& Hodgson A.N., 1998. A cladistic phylogeny of the family Patellidae (Mollusca: Gastropoda). Philosophical Transactions of the Royal Society of London B, 353: $1645-1671$.

Smith F.G.W., 1935. The development on Patella vulgata. Philosophical Transaction of the Royal Society of London Series B, 125: 95-125.

Smolders R., Bervoets L., Wepener V. \& Blust R., 2003. A conceptual framework for using mussels as biomonitors in whole efflent toxicity. Human and ecological risk assessment, 9: 741-760.

Sokolova I.M. \& Pörtner H.O., 2003. Metabolic plasticity and critical temperatures for aerobic scope in a eurythermal marine invertebrate (Littorina saxatilis, Gastropoda: Littorinidae) from different latitudes. Journal of Experimental Biology, 206: 195-207.

Vat L.S., 2000. The growth and reproduction of Patella granularis (Mollusca: Patellogastropoda) on the southeast coast of South Africa. PhD Thesis. Rhodes University, South Africa, 247 pp.

Vermeeij G.J., 1973. Morphological patterns in highintertidal gastropods: adaptives strategies and their limitations. Marine Biology, 20: 319-346.

Viaroli P., Bartoli M., Giordani G., Austoni M. \& Zaldivar J.M., 2005. Biochemical processes in coastal lagoons: from chemical reactions to ecosystem functions and properties. Indicators of stress in the marine benthos. IOC worshop report, 195: 27-30.

Warwick R., 2005. Taxonomic distincness as an indicator of stress in the marine macrobenthos. Indicators of stress in the marine benthos, IOC worshop report No. 195: $10-11$.

Wilson E.B., 1904. Experimental studies on germinal localization. Journal of Experimental Zoology, 1: 1-72. 